\title{
Ultras in Trnava: History, Activities and Ideology
}

\section{DANIELA KUŠNIEROVÁ}

Department of Ethnology and World Studies, University of SS. Cyril and Methodius in Trnava kusni@centrum.sk

\section{ABSTRACT}

The environment of football fans is unknown phenomenon for the rest of the public. This article offers basic view on formation and functioning of the most numerous and the most active ultras group in Slovakia, Trnava fans. First part of the text encompasses a history overview of ultras movement, as well as an overview of basic activities of ultras fans during a football match and also outside of it. The second part of this text deals with the most debated activity of football fans, which is violence during a football match.

KEY WORDS: football, ultras, fan groups, divisions, crowd, choreography, chants, symbols, violence

Sport has become an integral part of the general public's cultural and social life not only in our country, but worldwide. Influence of sport on human life is most apparent in the environment of fans of the world's most popular team sport, football. Popularity of this sport is shown by great numbers of football supporters worldwide. Like the game itself, activities of its supporters have also gone through several stages. Over the course of years, the football fans have been gradually developing increasingly worked-out forms of activities focused on support of their favourite sport, resulting in formation of a distinctive 
lifestyle. This contribution aims to give more details on one of the most significant stages of this phenomenon, which is formation and spread of the Ultras. ${ }^{1}$

Due to the lack of specialised literature related to the issue of football supporting in Slovakia, as well as due to the difficulty of the examined environment ${ }^{2}$, major part of the information used in the present text is based on results of field research, which was carried out in the environment of football fans in Trnava in the period between 2007 - 2009, in the form of participant observation. The information used herein was completed by information obtained by interviews with several respondents, as well as by information gained by a questionnaire survey which was, however, participated by only very small number of respondents, just as in case of the interviews ${ }^{3}$. In addition to the football supporters' answers, the present text has used some internet sources, including websites created directly by fans, offering a significant source of self-reflective information. Major part of the contribution is based on information given in a Masters Dissertation, completed by information obtained by an ongoing research.

\section{History and Ideology of the Ultras Movement}

All the fan groups have always aimed primarily at efficient cheering and supporting of their club, players and home town of the club, as well as presentation of themselves. The fans are often believed to be the twelfth player. They have received such designation particularly thanks to their regular active attendance of football matches both on their own ground and on the opponents' pitches. Consistent preparation and consequent realization of various forms of the club support (both verbal and visual forms) rank among reasons of the Ultras formation.

For more see in the part History and ideology of the Ultras movement.

Likewise in other countries, the football supporters in Slovakia have also created their specific way of thinking and behaviour, with the basic rule consisting in non-provision of information to other people than their own group members.

The reason for a small number of respondents, that participated in questionnaire research and interview, is the fact, that the research took place in a period when a boom of the Ultras groups reached its peak in our conditions. This boom attracted great attention of mass media as well as of the public. The inaccessibility of informations on isolated groups of football fans often caused, that mass media provided inaccurate informations to the public. This caused, that the rule of non providing of any information outside of the fan group, was strictly followed. Respondents, whose statements are implemented in this text, participated on a questionnaire research, or gave an interview only because of the friendly relationships, that we formed. 


\section{DANIELA KUŠNIEROVÁ}

Owing to the lack of available literature, history of the Ultras is very difficult to summarize. In this case there is use of the internet source, offering short history and ideology of the Ultras recorded by the fans themselves.

According to the available source, the word ultras is derived from the Latin expression ultro or ultra, meaning beyond, over or above. The movement members themselves perceive the term ultras as "being more than just regular football fans" According to the same source, Torcida ${ }^{5}$ Split from the former Yugoslavia countries, established in 1950, is considered to be the first European Ultras group. Torcida exists to this day as an organized fan group of the present-day Hajduk Split of Croatia. Torcida Split founders were probably inspired by the Brazilian "torcidas". They saw active supporting by the Brazilian fans on the 1950 World Cup in Brazil. However, groups of the Brazilian fans were not officially associated then, and symbols and pyrotechnics were used in an unorganized way. The 1960s saw spread of the Ultras movement in Italy, where it has adapted relatively well, laying the foundations of fans as creators of a specific lifestyle ${ }^{6}$.

Over the course of following years, the fans were gradually forming their specific lifestyle and rules. The fundamental and invariable idea of the movement, further adopted by groups all over Europe, is that those fans are considered to be the Ultras members that support their team actively, observing several basic principles:

- they never sit down during a match

- they support their players regardless of the match result

- they attend as many matches as possible both on their home ground and on the opponents' pitches. ${ }^{7}$

The movement has spread all over Europe relatively quickly. According to the above mentioned source, numbers of the Ultras groups and their members vary: "there can be tens, hundreds or even thousands of them, depending on the nation's mentality or significance of the club." Preparation and realization of so-called choreo - i.e.

Added on 13/04/2009: http://www.hooligans.cz/view.php?cisloclanku=2008120005

5 The name "Torcida" is the Brazilian Portuguese word for "supporters".

6 Added on 13/04/2009: http://www.hooligans.cz/view.php?cisloclanku=200812005

7 Added on 13/04/2009:

http://ultras.sk/index.php?option=com_content\&task=view\&id=326\&ltemid=268 
choreography, "which is the prettiest expression of the club support," ${ }^{8}$ rank among the overriding activities of the movement members. The choreo has various forms and will be described in details below. One of the next important activities of the Ultras groups all over Europe is, besides the mentioned choreo, fight against the modern football ${ }^{9}$. The main principles and ways of fight against the modern football in Trnava will be clarified below. In addition to the choreography, the Ultras members present themselves by clothes or some other products of the Ultras groups.

The original effort to uplift the atmosphere in a stadium and unify all persons interested in such activity has in the course of time developed into certain lifestyle, resulting in formation of a specific group and its own culture, opinions, attitudes and behaviour. Furthermore, the internet source provides for other important characteristics related to the way of life of the Ultras fans:

- The Ultras member does not exist for the outside world, his name is unknown for the strangers, and only his friends know him.

- He often covers up his head with a hood and his face with a scarf. He does not wear common-style clothes, he is not enchanted by fashion trends, and he does not care about introductions. Once he gets on a train, he is recognized even if he's not wearing any clothes of his club.

- The Ultras members are different. Some of them wear clothes of their club, other ones wear clothes of their group and some of them do not even have any clothes of their group or club. There are members who move within a group, and there are some of them who start a group of their own.

Added on 01/17/2015:

http://ultras.sk/index.php?option=com_content\&task=view\&id=326\&ltemid=268

9

For Ultras fans, or for a real fans, the word football does not encompass only the game alone, but also its fans and their relationship to the game and the way of life, which they formed in respect to the game. The expression "the fight against a modern football" created by the fans, does not describe only a fight against implementing of some new rules considering the game, but primarily a fight against implementing of rules and restrictions considering the fans, such as selling tickets on a name, obligation to sit during the whole match, restrictions of stronger cheering in the event of scoring a goal and so. 


\section{DANIELA KUŠNIEROVÁ}

- One remains the Ultras member even after taking off a scarf after a match or after coming back home from a trip. He is himself ${ }^{10}$ seven days a week.

- When he meets common people, they do not understand him, and he is not interested in their understanding! He does not explain his lifestyle to anyone, and he does not care about opinions of other people.

- An older member of the Ultras sets an example for the younger ones and is respected by them. A young member of the Ultras appreciates it when the older members call him among themselves; he accepts criticism and draws a lesson from it.

- There are various Ultras members; however, they are bound together by something. They are bound together by their relation to the club and common hatred towards opponents. They are bound together by the great feeling when they set off on a long trip, by marches through the enemy's town, sense of security from friends which keep them company on their way home from a trip. They are bound by a given cigarette or fight for a window seat on a night train. They are bound by mutual help and hunt for fight, by their collective mentality. All of this is at the same time moving the Ultras members away from the outside world, their worried parents, classmates and non-understanding teachers.

- The Ultras member attacks in case of attack, helps if necessary.

- The Ultras does not mean violence for no reason. It is defence of a lifestyle which is in danger, fight against tickets issued on names, paid TV stations, new modern society, and particularly against oppression. The Ultras is even more, it encompasses feelings which cannot be told in words, which are incomprehensible to common people (IRRIDUCIBILI LAZIO). ${ }^{11}$ 


\section{History, Activity and Ideology of the Ultras of Trnava}

The Ultras fans of Trnava form the most numerous and the most active group in Slovakia. Due to the relatively extensive activity of the Trnava Ultras fans, and in the interest of the most accurate clarification of the issue, the text contains following fields of activity:

a) History of the Ultras of Trnava

b) Activities of the Ultras fans during football matches (organization of a crowd, choreography)

c) Symbols of the Ultras

d) Secondary activities of the Ultras (protests)

e) The Ultras and violence

\section{a) History of the Ultras of Trnava}

First attempts to record and mediate their own history have occurred among the fans of Trnava recently. However, they still express themselves very carefully with respect to the fact that the information is publicly available, because, likewise in other European Ultras groups, the basic rule regarding non-provision of information to other people than their own group members applies here, too.

Various manifestations of unorganized supporting began to appear at the beginning of formation of the fan-base history in Trnava. ${ }^{12}$ These manifestations consisted mainly in spontaneous outcries which have in many cases resulted in positive response in the form of involvement of other supporters, or they have, more rarely, faded out without any response. "Trnava, go" ("Trnava do teho") is one of the oldest outcries of the unorganized supporting period, and it has been used to this day.

The first group similar to the present-day Ultras groups was created at the beginning of 1990s. It was called Alkyfans and it was, at the beginning of its existence, seated on the was founded in 1923. The club has changed more names during its history. The club has been active under the name "Spartak" since the 1947/48 season. 
South curva of the Trnava stadium ${ }^{13}$ before reconstruction ${ }^{14}$, where the "hard core"15, the real fans were concentrated. Alkyfans members were inspired by various advanced Ultras groups of the world, taking over "loud chants and "clenched fists"16 from England, enthusiasm for cheering and entertainment on the terraces using flags on pole, scarves, etc. from Italy, and fashion to wear club colours from the Western Europe and the Balkan." (R4, W.A. c.a., 23 years old).

Two new groups were formed from the Alkyfans members with time. At first it was a hooligans group Red Black Wariors (hereinafter referred to as RBW) established in 1996, and later, in 2001, it was a group called Southsidetrnava (hereinafter referred to as SST). Alkyfans group has not disappeared after formation of the other groups; however, it has a minimum number of active members at present.

SST has taken over all the activities related to supporting of a club, and it was concentrated in a crowd on the South curva. The group has created the first choreographies on both home and opponents' pitches, "trying to move further on in the Ultras activities with each match, achieving their goal." (R4, W.A. c.a., 23 years old). Another numerous and at the same time active Ultras group, Northsidepatriots (hereinafter referred to as NSP) was established in 2005, seated on the North curva in the same way as in times before reconstruction of the Trnava stadium. Since its formation, the group has created various choreographies on a high European level ${ }^{17}$. The group is also considered to be different because "you will not find as many young boys (already from 10 years old) and girls anywhere in Europe but in the NSP crowd on the North curva. NSP can be termed as a "seedbed" of the new fan blood with the "Spartak" diagnosis." (R4, W.A. c.a., 23 years old).

13 For illustration, see annex No. 1.

14 Reconstruction of the football stadium began in 2013, and its completion is planned for 2015.

15 Before the organized supporting was created, all kinds of fans were considered to be the "hard core", regardless of their allegiance to a group or ideology, i.e. violently and non-violently acting fans, whereas the designation was related particularly to a group of fans concentrated in a crowd or actively supporting fans both at the home football matches and during the football matches taking place in the opponent's stadium. Currently, primarily the Ultras fans are considered to be the "hard core". The "hard core" designation is, regarding the currently applicable division into types and groups of fans, relatively obsolete, as it is denoting the originally undivided groups including all kinds of fans.

16 Chanting and shouting supported by raised hands with clenched fists.

17 For details, see pictures in annex. 
Currently there are several smaller and larger Ultras groups in Trnava, called also "groups" or "divisions", created on the basis of friendly relationships or places of living. The groups present themselves with their own flags, and presently the best known groups are Under clock Deads (the name is original, hereinafter referred to as UCD), Wild West ("Divoký západ”, the name of the group does not shortens), Gang of Pieštany ("Banda pieštanská" the name of the group does not shortens) originally called Fanatics of Piešt'any ( "Piešt'anský fanatici" the name of the group does not shortens), Line ("Linka" the name of the group does not shortens), Zátvor ${ }^{18}$, and others. Some members of the smaller groups are at the same time members of large Ultras groups, such as NSP and SST. All the Ultras groups are unofficial.

Fan club of Spartak Trnava ranks among the official fan associations, and it has also gone through several changes. It was created on 10th April 1966 as Spartaklub, a club of friends of TJ Spartak Kovosmalt Trnava. After a forced termination, the club restored its activity on 18 February 1988 as "Club of Supporters of the Spartak TAZ Trnava". In the 1990s, it has changed its name to "Fan Club of Spartak Trnava", encompassing about 150 members. Currently it acts under the name White Angels, citizens association ("Bíli Andeli, o.z. ’).

\section{b) Ideology of the Ultras of Trnava}

The football fans have over the course of years created a specific kind of group, increasingly moving away from the way of thinking and behaviour of the rest of the society. Difference of opinions and attitudes is even more specific due to the fact that the football supporters have a distinctive way of advancing their own group ideology, and all efforts to understand them by the uninvolved persons are complicated by complete isolation of these groups, which refuse to communicate with the environment or explain the way of their thinking and behaviour.

The primary goal of the Ultras is to "uplift the level of supporting, unify supporting and supporters, enhancing the atmosphere in a stadium." (R1, SST, 36 years old). Using efficient cheering and supporting, they present their club, home town, as well as 
themselves. Attendance of the football match means for the fans first of all distraction from their daily duties, meeting friends, having fun and filling up their spare time in this way. ${ }^{19}$

Rules of the Ultras are not written, however, majority of individuals is familiar with examples and behavioural standards. They obtain information during regular active attendance of football matches or in company of the older members, who are creators and propagators of the applicable examples and behavioural standards. The basic generally applicable values among the fans include:

- loyalty to friends, the "big family",

- loyalty to the club, or more precisely to Spartak Trnava,

- support of the club through active attendance of the football matches,

- loyalty to the older group members, who are creators and propagators of the values,

- creation of symbols enabling identification of groups, which are respected by the group members.

In addition to the generally applicable group values, there are also individual values, meaning that despite the fact that an individual identifies himself with the group values completely, at the same time he follows values of his own. Such individual values are allowed in case that they are not contrary to the generally applicable group values.

Basic standards of the Trnava fans include:

Respondents' answers to a question: "Why do you attend the football matches and support Spartak?":

"I love football, it gives me almost everything I need (sometimes I even think it gives me more than my wife does). Football gives me strength to live. When I am sad, I think of one of our trips or a chant, and it makes my life easier. I have met a lot of friends in Spartak, and therefore football, particularly Spartak, takes pride of place in my heart, and I believe it will remain this way forever." (R4, W.A. c.a., 23 years old).

"Because it is closest to me and it has always attracted me most. I can get rid of excess energy and, vice versa, draw new, positive energy there. I take my mind off things in an incredible way, meet my friends, and get lots of experiences. It is a beautiful game full of emotions, amazing actions and sport performances. I always have wonderful times at a football match..." (R8, BP, 26 years old).

"It means a lot to me, it is being with my friends; together, we go through success and celebrate it; we overcome disappointments; we experience amazing trips; family of Spartak is huge and it involves meeting new friends." (R3, NSP, 24 years old). 


\section{Ultras in Trnava: History, Activities and Ideology}

- observance of the group rules and loyalty,

- respect of the older group members,

- respect of the group leader,

- respect of the club and its history,

- manifestation of respect and gratitude for the possibility to use the created club

symbols.

Way of thinking and behaviour of the Ultras of Trnava differs from the lifestyle created by the Italian Ultras only in some details. First of all it should be noted that the environment of the Trnava fans has been under transformation in the last decades, with the priority to achieve stability of the fan base in Trnava. The transformation lies primarily in efforts to define the basic principles of operation of individual groups, as well as in clarification of priorities and authorities of these groups.

The Ultras of Trnava are trying to keep their identity secret from the public as well as from the occasional visitors of the football matches. Spectators ${ }^{20}$ or in some cases also fans $^{21}$ interested in integration among the Ultras in times of the club's success are only rarely familiarized with the basic standards, values and current behavioural examples of the group. As a matter of fact, spectators or in some cases also fans usually leave the group when performance of the club is in decline. Due to such incessant migration ${ }^{22}$ and change

A spectator is considered a passive observer of the game not influenced by rivalry of the teams, with neutral view of the match. The spectator is interested primarily in the game action and result. $\mathrm{He}$ is not associated with the club, does not wear club symbols and does not identify himself with the club. He does not know rituals of the club's "die-hard" supporters, making him unbiased and increasing his objectivity to assess the game and results. A spectator attends matches only rarely, giving preference to mediated watching of the matches (TV, radio, internet, paper), and he watches also other sports besides football (quotations of MAREŠ-SUCHÁNEK-SMOLÍK 2004).

21 A fan is characterized as a person bound to the football by his favourite team or player. He has certain expectations of the match result and due to his identification with the team, he can experience success and failures of the team in a more tempestuous way, responding to various situations during a match, such as foul plays and others. A fan presents himself with a club clothes, perceives himself and persons similar to him differently, and understands division to "us" and "them". Football is his only favourite sport (quotations of MAREŠ-SUCHÁNEK-SMOLíK 2004).

22 The Ultras members amount to hundreds in Trnava, so the remaining number of persons attending home matches as well as matches on the opponents' pitches count among the migrating members. 
of supporters, identity of the Ultras members is difficult to protect, particularly in case of the most active ones, who are the most "visible" for the environment and whose identity is often revealed to the so-called "unchecked" persons.

The fact that the Ultras member "often covers up his head with a hood and face with a scarf" has its specific reasons in case of the Ultras of Trnava. Ultras do not remain covered up during the entire match. They use the cover-up only in case of imminent risk of the identity revelation, for instance during a town march when there are journalists or newsmen in the vicinity, if clash with the police breaks out, or if there are flares burnt in the stadium, etc. Currently, covering up during a town march or a football match is forbidden by law. Apart from the typical clothes of the Ultras, the Ultras members dress up to their own taste and discretion. In this case it should be noted that the Ultras members of Spartak Trnava wear clothes made by the group members themselves, they do not buy clothes from an official fanshop.

They present their favour to the club and membership of the Ultras everywhere, at work, in school, at home or on holidays, etc. Ways of the presentation vary, depending on the specific environment and available tools. Home is the easiest place to create the required environment by hanging out flags, scarves or posters, or possibly by painting symbols on the walls. In the environment which does not provide good conditions for presentation of their membership, the Ultras members often use smaller objects such as bracelets, key cases, stickers, etc.

Considering the mentioned character traits of the Ultras members, it is understandable that the rest of the society often does not understand their behaviour. Despite the fact that the Ultras members do not care about opinions of the majority society, they are frequently unsatisfied with the statements and image media have been creating about the fans. On the ground of disputed statements by media, another basic rule was established by the Ultras: no communication with media or anyone trying to publish the inside information.

Transmission of information from one generation to the next has been close to the people since time immemorial. This is also the case of the fan group in Trnava. However, this fact does not concern solely the Ultras, as the movement in its present form began to spread only from 2000. It relates also to other types of fans and the hooligans group. In spite of that, the situation is in this case complicated by the high number of fans who want to join the Ultras, making closer selection and verification of each member impossible. As a consequence, the older members often isolate themselves from the younger persons or the ones they do not know, for fear of disclosure of confidential information and revelation of their identity, or disclosure of some activities. Due to such isolation, the younger or 
uninvolved supporters do not understand the behavioural rules and standards, and therefore decide to act using their discretion. Such behaviour often results in negative effects, creating negative image of the Ultras as a whole. Despite that, if a younger supporter is really interested in becoming a fully-fledged member of the Ultras group, he can find his way to win favour with the older members.

\section{c) Activities of the Ultras Fans During Football Matches}

Since existence of the fan group depends on existence of a club, it is obvious that all activities of the Ultras are focused on the football matches. Football match is at the top of the activities of the Ultras. Despite the fact that it concerns supporting of always the same club, there is certain difference between the home matches and the matches played on the opponents' pitches.

\section{Home matches}

Part of the Ultras ideology is a "compulsory attendance of a match". "Being present in a stadium is our duty. A real fan doesn't care about weather or entrance fee, and particularly he is not influenced by any TV broadcast on STV channel ${ }^{23}$. A real fan will always be present on $S A M^{24}$." (R2, NSP, 30 years old). Even though forcing people to attend a football matches unless they want to is impossible, attendance of the Ultras is compulsory. Similar rules or statements serve as a warning for the younger members to make them observe one of the basic rules of the Ultras. However, for most of the Trnava fans, particularly the Ultras members, attendance of a match is not an obligation, but rather a matter of fact.

Football match at home environment typically begins by meeting of most of the fans in pubs. Majority of fans have their permanent place of meetings in their favourite pub. During these meetings they usually discuss football, result, common experiences, and so on.

Preparation of choreo is an important before-the-match activity for the active Ultras members. Not all the members are involved in the preparations within a group which seats and prepares choreo on its part of the terraces. There are usually some individuals meant to

\footnotetext{
23 Abbreviation for the Slovak television channel.

24 Abbreviation for the Stadium of Anton Malatinský.
} 


\section{DANIELA KUŠNIEROVÁ}

project a choreo, provide for material, produce and distribute it on a stadium. Production and distribution of the materials is usually entrusted to the younger members of the Ultras. Ready-made parts of the relevant choreography are usually placed on seats of the curva which has prepared the choreo.

Shortly before the match begins, collective club flags are hung up. If a group or a division has its own flag, there is usually one member meant to take care of the flag and bring it to every match. If he cannot attend a match for some reason, he gives the flag to another member he trusts to.

The Ultras members gather in a stadium in a common "crowd. ${ }^{\prime 25}$ In order to achieve better coordination of the crowd members, there is always a crier, usually the majority group leader, to organize cheering and supporting in a crowd during the match, determining order of individual chants and providing for better efficiency of the supporting. The crier's role is not easy, as it is not only about suggesting and pre-singing of a chant, he often has to unify all the attendants, a complicated task particularly in case of larger numbers of the match attendants, and at the same time he has to galvanize all the participants into joining the chant. To make the communication of the crier with the crowd members easier, megaphones were put into use in the past. Nowadays, the crowd has installed a sound system on the home terraces. The Ultras fans are standing and cheering during the whole match, they sit down only as part of the choreo. Part of the choreo is also formed by scarves which are, for example during the club opening anthem, raised above the fans' heads. Regular part of the choreo is also formed by clapping in the 20th and 70th minutes of the match, usually joined by the entire stadium.

\section{Trips}

Trip is a football match taking place on the opponent's pitch. For a fan it means travelling to another town to see the match. On the trip day, meetings in permanent pubs are replaced by means of transport such as cars, buses, minibuses or trains. Majority of fans are seated in the sector for guests, but some of them, usually spectators or in some cases also fans attend also terraces of the home team.

Choreo is realized in the same way as at the home matches, the only difference is in the way the choreo is arranged. The choreo is realised shortly before beginning of the 
match, and is often distributed directly to the fans. In some cases, when the fans travel by a specially dispatched train reserved for the fans, some smaller objects related to the choreo (e.g. whistlers, balloons) are distributed directly on the train, rarely also on the buses or during meetings on the filling stations on their way to the match.

Attendance of the trip is compared to the attendance of the home match of greater importance. It has several reasons. Out of Trnava, the fans present their town, club and themselves more visibly, and the presentation is observed by the opponents' fans, who attend the matches in Trnava very rarely or not at all.

Experiences and funny stories are not only told during the trips, but are also experienced. Most of the memories and experiences are related to such trips. A regular trip attendant can be identified according to how many stories from other trips he knows, whether as a direct participant or as a listener.

\section{Derby}

From the fans' point of view, derby is one of the most important matches of the season. In case of derby, both home match and match on the opponent's pitch are of the same importance. Derby always requires an extraordinary preparation, because the competition does not take place only on the pitch, but also on the terraces. There is only one derby for the fans of Spartak Trnava, the one with the biggest rival of Trnava - Slovan Bratislava. This match means "top of the season, even if another half of the season should follow" for the fans (R4, W.A. c.a., 23 years old). Derby with the biggest rival of Trnava, Slovan Bratislava, is associated with the exceptional preparation and is often accompanied by unexpected events or disturbances.

\section{"Crowd"}

Crowd is an important part of the Ultras of Trnava, with its place on the terraces, concentrating all the actively supporting fans during the football match. The crowd began to form already before spread of the Ultras groups, and in those times it was a seat of the Trnava fans "hard core". At present, mostly the Ultras groups are concentrated in a crowd, enabling advance in the crowd activities. However, it is not excluded that more groups meet in the crowd, depending on the place (during the trips, for example, major part of the sector for guests is considered to be a crowd, and supporting is joined by majority of the attendants, even if they do not rank among the Ultras group or hooligans) and significance of the football match (during derby, for example, also wider range of spectators meet in the 


\section{DANIELA KUŠNIEROVÁ}

\section{Ultras in Trnava: History, Activities and Ideology}

crowd). The crowd has a rich history and is the cultural centre of the contemporary Ultras fans. It is formed not only during the home matches, but also during matches taking place in other towns. Everyone interested in the atmosphere formation in the stadium is gathered in the crowd. It has its own rules and permanent members providing for its operation.

The crowd began to form already in the 80 s of the 20th century. At the beginning of its existence, it was located on the South curva. By the end of the $80 \mathrm{~s}$, the crowd shifted to the West curva, closer to the North one, where it acted for two years. At the beginning of the 90 s, the crowd returned back to the South curva, where the first Ultras group, Alkyfans, was formed, which began to organize the crowd activities. The crowd has remained on the South curva to this day, however, other groups were formed besides the crowd, taking part in the crowd presentations and making its activities more efficient. Since 2000, another crowd began its formation on the North curva. In 2009, leaders of both crowds agreed to unite the crowds and subsequently change the positions of the crowd in turns during the home matches, and the crowd now meets once on the South curva, another time on the North one. The change came up after a leader of the North curva crowd had left, causing malfunction of the crowd. Currently there is only one crowd on the temporary terraces in Trnava due to reconstruction of the football stadium. The reconstruction should be completed in 2015, and complete change of functioning and location of the crowd is expected then, too.

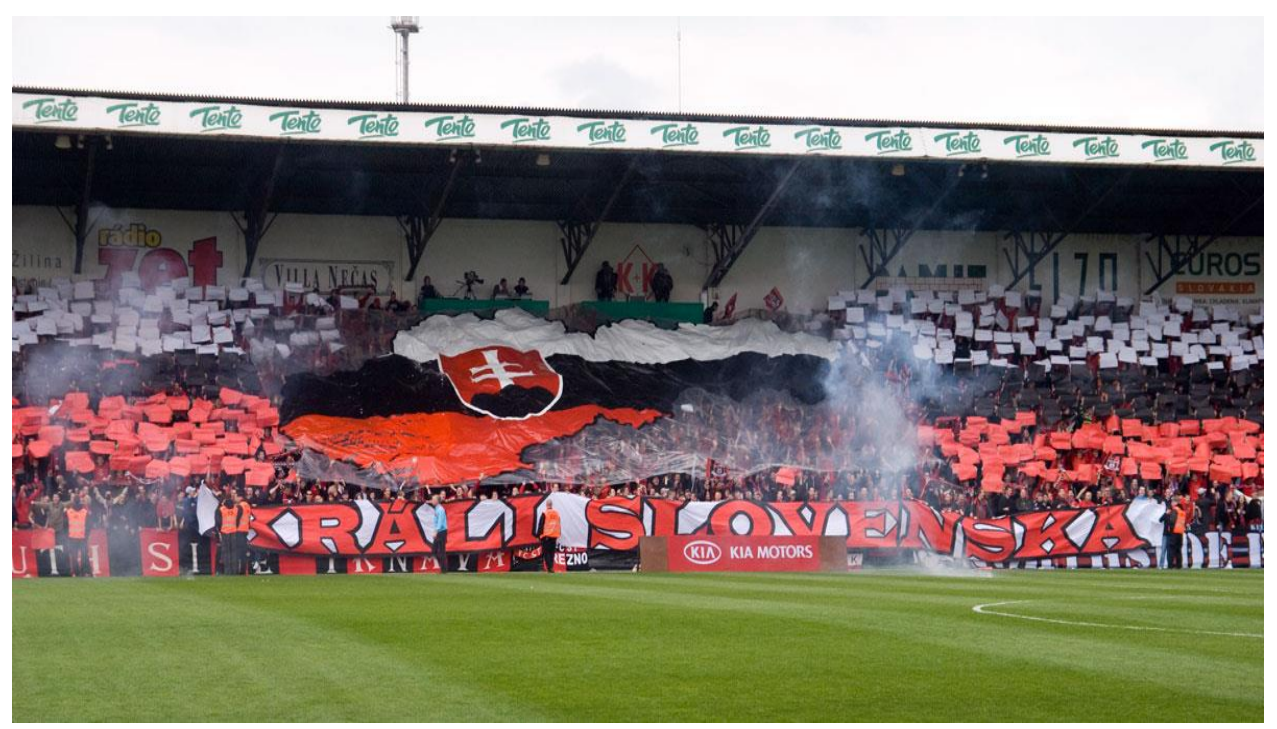

Figure 1: Cardboard choreo combined with Burning-through choreo. Photo: author. 


\section{"Choreography"}

1. Choreo or choreography is formed by various visual creations This activity is not an exclusive idea of the contemporary Ultras movement, as the first signs of the choreo have appeared long before spread of the Ultras groups in Trnava. However, the Ultras members have taken over this activity as their basic activity. The most frequently used types of the choreo are:

- Cardboard choreo ("kartónovačka") - visual creation composed of several sheets of paper of various sizes and colours. This choreo requires larger number of people.

- Burning-through choreo ("prepalovačka") - transparent film of various shapes and sizes with paintings or writings, usually accompanied by light effects. The burning-through choreo can be realized in two ways, either raised above the fans' heads or hung on railings or a fence.

- Argentina ("Argentína") - consists of throwing small pieces of paper and confetti in the air.

- Sector choreo ("sektorovka") - large piece of paper or another material with various paintings or writings raised above attendants' heads directly on the terraces.

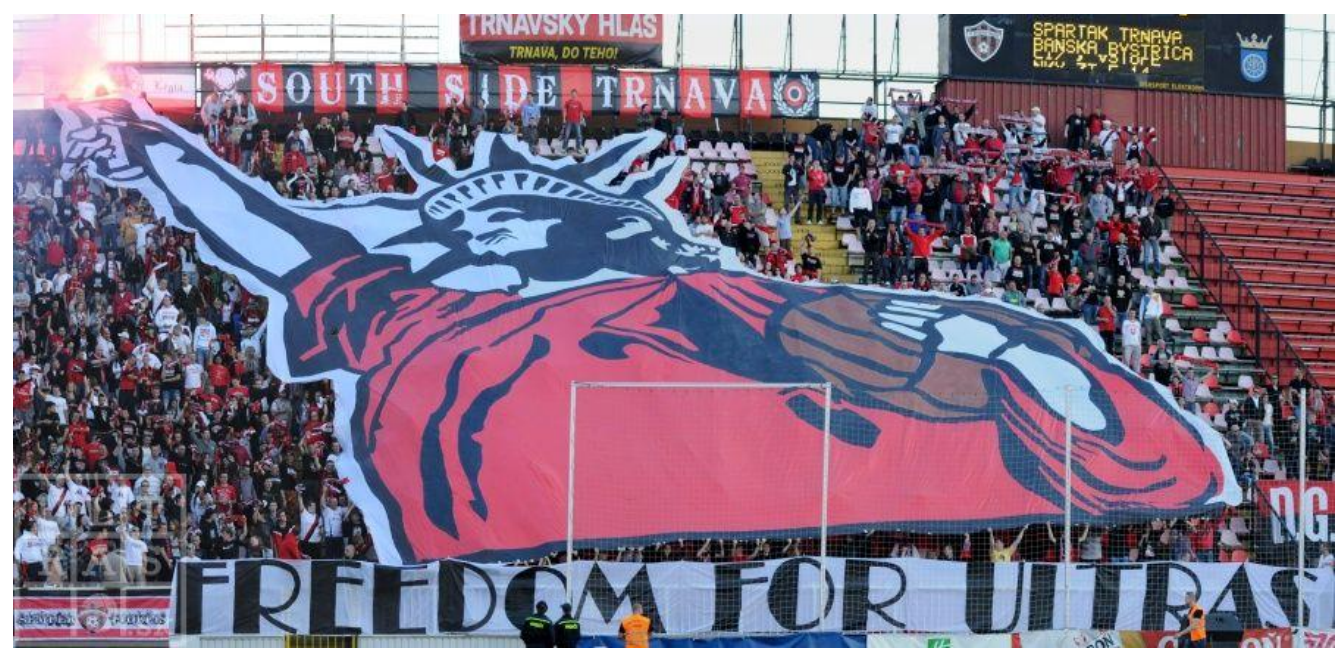

Figure 2: Sector choreo. Photo: author. 


\section{Ultras in Trnava: History, Activities and Ideology}

- Live choreo - in contrast to the above mentioned, this is usually realized with clothing of the fans in a match, they often wear e.g. T-shirts, raincoats, caps and so. Live choreo is performed only seldom, because it is costly.

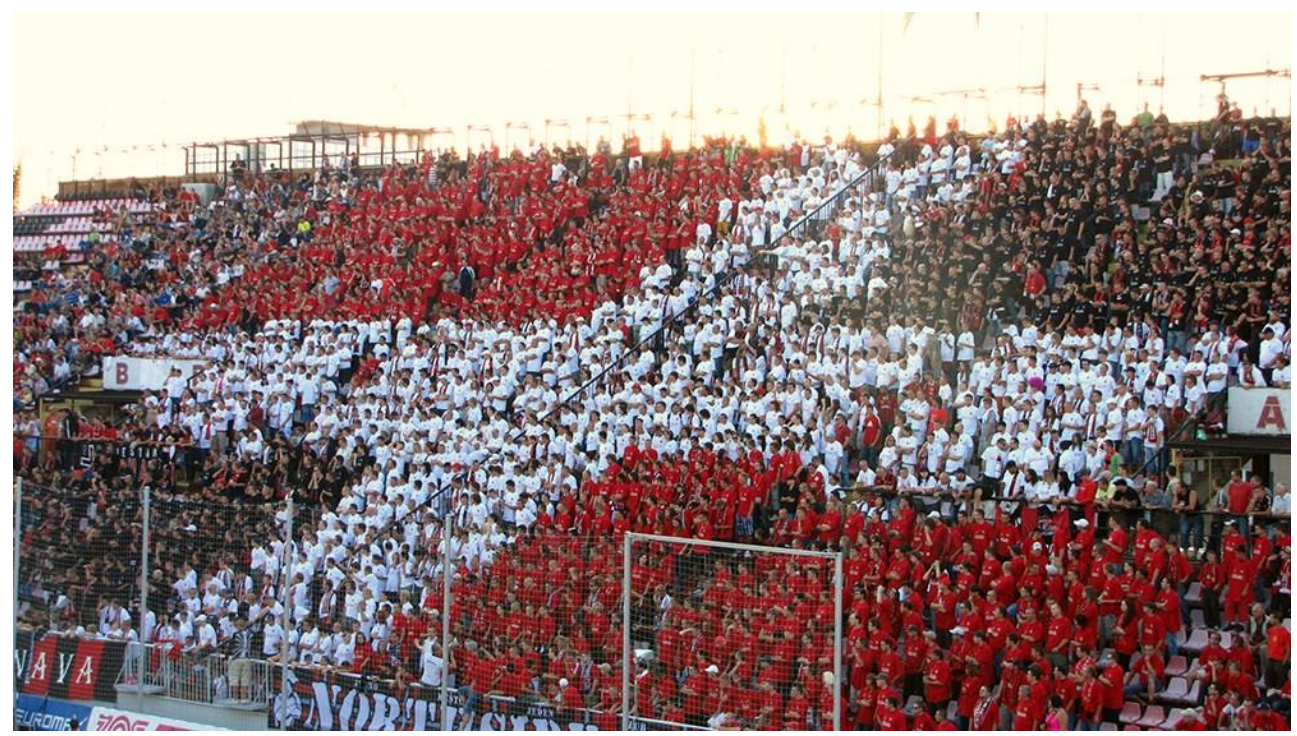

Figure 3: Live Choreo. Photo: author.

2. Part of the choreography of the Trnava Ultras is cheering. This activity is nowadays highly sophisticated. Apart from the chants, other elements are added to the cheering and supporting, aiming to make the cheering better and more efficient. The cheering includes following forms:

- Clapping ("vytlieskavacka") - is usually realised in the 20th and 70th minutes of the match. Shortly before the 20th minute, the crier asks all the football supporters in the stadium to raise their hands above their heads. Exactly in the 20th minute, following his example, all of them clap their hands and shout "Spartak". They begin in a slow pace with longer pauses, gradually intensifying the pace and shortening the pauses. Once the clapping and cheering reach certain pace, they begin to slowly fade out. The same progress is repeated in the 70 th minute of the match. 
- A crier asks the crowd members to hold shoulders of one another, and once they do so, they start jumping together, shouting "ole, ole vivat rossoneri" ${ }^{26}$

- A crier asks the crowd members to sit down, once seated, they start swinging from side to side in a rhythm of the sung chant "Our Trnava" ("Trnava naša"), repeating the chant several times (the number of repetitions depends on the crier), and after the precisely set number of repetitions, all the sitting fans jump up, shouting "Our red and black Trnava" ("Trnava naša červeno-čirna"). They continue chanting standing.

3. Chants $^{27}$ are the most frequent and the most widely used way of cheering. They always accompany a football match (unless boycotted), even in case that no visual creations were prepared for the match. They are rather popular, because they do not require any special preparation. The fans of Trnava draw ideas for the chanting melodies from the home environment, as well as from abroad. The chants do not represent any exclusive production of the Ultras fans; they were formed long before spread of the movement. However, they rank among the basic activities of the Ultras either regarding use of already existing chants or creation of the new ones.

The chants are created primarily in response to events related to the club and football in general. They are often seen as celebration of a club or a town, or humiliation and degradation of the opponents' fans, as well as of the greatest enemies of the football fans, the Slovak Football Association or the police.

The chant "Trnava is our town" ("Trnava mesto je naše") was created in response to long-discussed case of use of the vulgar language in a stadium. It dates back to 2008, and its melody is a reproduction of the Slovak folk song called Saturday to the fair I'll go (" $V$ sobotu na jarmok pôjdem").

The chant "Spartak, that is us" ("To my sme Spartak") was created in response to the club practices and lack of interest of the club management in needs of the fans, unfavourable results of the club, transfers of players within teams. However, these facts should not be reasons for fans to turn their backs on Spartak, because anything should happen, the true fan remains loyal.

26 In the manner of AC Milan Fans, in which we have the same club colours and some chants.

27 Texts of chants are published on official webpage of Spartak Trnava fans. 


\section{DANIELA KUŠNIEROVÁ}

The chants "Spartak, the white angels" ("Spartak bilí andelé"), "Our Trnava" ("Trnava naša"), "Spartak has a famous team" ("Spartak slávne mužstvo má"), "We will never leave you, Spartak" ("Spartak my t’a nikdy neopustíme"), "Spartak is better" ("Spartak je lepši"), "Bright star" ("Hviezda jasná"), "Spartak will win today" ("Spartak dneska vyhrá"), "The best on Earth" ("Najlepši na zemi"), Spartak, we will follow you" ("Spartak my pôjdeme stebou"), as well as other above mentioned chants "Trnava is our town" ("Trnava mesto je naše") and "Spartak, that is us" ("To my sme Spartak"), rank among the chants celebrating club, town and fans of Trnava. The chants responding to the situation of the Slovak football or humiliating an opponent are "Horto magiko" and "Slovanista".

- Shouting-over ("prekrikovačka") - is part of the cheering, the fans usually shouting over from one curva to another one, e.g. from the South curva to the North one, or a crowd is divided by an imaginary line in two parts, and they shout over to one another. The shouting-over is usually started by a crier chanting a melody "The other side answers" ("druhá strana odpovedá"), repeating it several times. Another variant is a chant "the entire stadium chants with us" ("celý štadión spieva s nami"), followed by shouting-over or a chant. The shouting-over includes e.g. "Spartak - Trnava" or "Horto magico ${ }^{28 " .}$

Following outcries are also rather common:

- to media - one, two three, f..kTA3 ${ }^{29}$;

- to the police - eins, zwei drei scheisse polizei, police state, f..k the police, ACAB;

- to the opponent's fans - whole Bratislava jude, jude, jude, f..king yellow and green

Žilina, beat and beat and beat the Hungarian to his head; Why is there so few of you, you sh..heads, why so few of you?

\section{d) Symbols of the Ultras}

Fans as a whole express themselves using symbols. This way of expressing is significantly developed in case of the Ultras members, and creating of new symbols and passing them on the rest of the whole has become another basic activity of the Ultras.

28 The name of the choreo was adopted from one of the foreign ultras groups, it is choreo combined with shouting-over, the text of a choreo is accessible on a website www.ultrasspartak.sk.

29 TA3 is a Slovak TV channel.

DOI: 10.1515/eas-2015-0004 C University of SS. Cyril and Methodius in Trnava. All rights reserved. 
Dress code - the Ultras have a specific way of dressing up, making their own clothes in colours of the club, i.e. black, red and white, or combining these colours. Besides hoodies, T-shirts and caps, each fan has a scarf. A scarf is not worn only by the Ultras members; it is a part of clothes of almost every fan attending a match. Even though clothes made by the Ultras are not typical for every visitor, and there is not even a rule determining that they should be owned solely by the Ultras members, not wearing a scarf is rather an exception than a rule. However, the Ultras wear only the clothes made by the group members themselves; they usually do not wear clothes bought in an official fanshop.

Flag - is one of the most important symbols of the club. In addition to the basic club flag, part of the equipment is represented by the flags of individual groups and divisions. Importance of the flags is characterized by negative response of a fan to request of one of the supporters to meet on a hockey match and bring flags of Spartak Trnava: "The flags are our pride and no one will make them dirty!! Don't combine hockey clubs with Spartak. It has nothing to do with us. If there is someone supporting a hockey club, it's his business and no one should mind. But as soon as you bring a flag in a stadium, you are representing opinion of all of us. And that's the point." (R2, NSP, 30 years old).

Flags are important symbols of the fans; they hang them out both at home matches and during the trips. Effort to seize the opponent's flag is another activity of the fans. Seizure of the opponent's flag is considered to be a heroic act, providing the seizing fan with respect of the group. The seized opponent's flag is burnt down. On the other side, losing of the flag means humiliation, not only of the flag bearer and its guardian, but also all of the fans.

Scarf - is owned by every fan, and making scarves is another activity of the Trnava Ultras. However, the scarf is not only part of the clothes, but it is one of the basic symbols of the fans. It serves as part of the choreography and is also used to express dissent and disapproval of the other clubs. Seizure of the opponent's scarf and burning it down is considered to be a heroic act, too. Same as losing the flag, also losing the scarf means humiliation for his owner. 


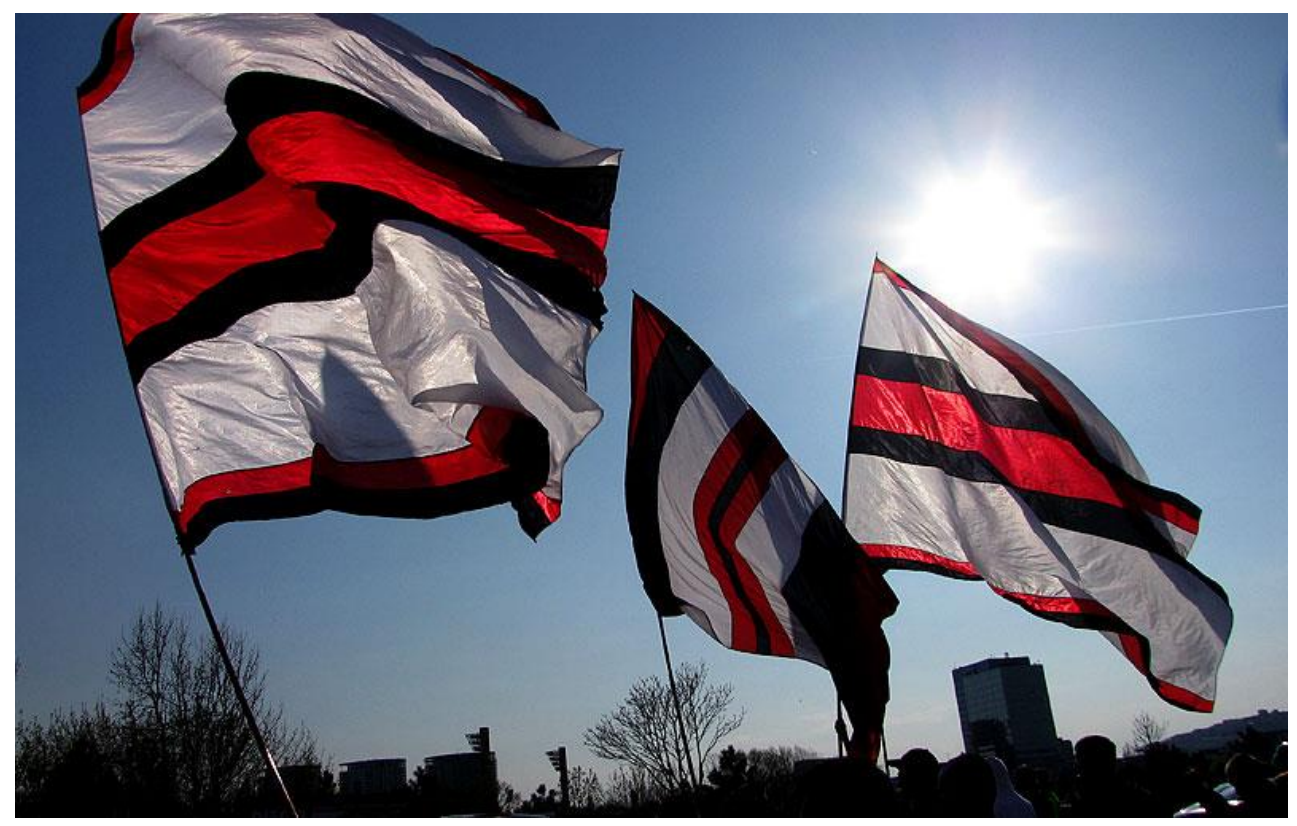

Figure 4: Flags on Pole. Photo: author.

\section{e) Other Activities of the Ultras Fans}

In addition to the above mentioned choreo, production of clothes, flags and other symbols, one of the most frequent activities of the Ultras is response to the current development in the football league, club and other football organizations. Strength of the group is most frequently demonstrated by protests or criticism.

The protests are most often related to:

- activities of the Slovak Football Association and the police,

- affairs in the club,

- bad results of the players,

- incorrect information of the public by media,

- some activities of the fans, either among own ranks or ranks of other clubs' supporters.

The most typical form of a protest is: 
Boycott - one of the most extreme forms of the protest. It is difficult to organize, because this form of a protest can be efficient only in case that it is participated by the largest number of the fans possible. At the same time it is the most difficult way to reach an objective, because a group with so many members covers up various opinions, and missing out a match is inconceivable to many fans. If a required effect should be reached, it is necessary that the sector for guests or the home stadium remain really empty. Taking into consideration the basic rule of the Ultras, to attend every match in order to support players and present the club, town and themselves, it is obvious that such solution is used only in the last resort. Bad results of the players are no reason to boycott a match. Contradiction between observance of the basic rule on attendance of each match and way of defence of the group's interests in times of danger can be illustrated by two cases:

Restriction of tickets as a punishment - boycott of the trips to Petržalka ${ }^{30}$ and Zlaté Moravce - the boycott was preceded by events from the Slovak Cup final in Žilina (of May 1st, 2008) which have not been clarified to this day. After this match, the Slovak Football Association has, besides fining the fans, restricted the amount of tickets for the guests' fans to four hundred tickets, under condition that only the fan club members or people the fan club members vouch for can obtain the tickets. The Ultras of the Spartak have responded to these measures by an appeal to boycott the last two trips of the season, a trip to Zlaté Moravce and Petržalka. Boycott of the match in Zlaté Moravce (played on May 17th, 2008) was a success, only a small group of fans appeared in the sector for guests with a transparent reading "ALL OF US OR NO ONE", joined by a few supporters from the surrounding villages, probably not aware of the boycott. The boycott continued also during the home match with Žilina, where several banners were presented, expressing disagreement with orders of the Slovak Football Association. Postponed match of Petržalka - Trnava was boycotted not only by attendance, but also by pictures and articles on the fan websites. A brief report of the course of the match appeared on the Spartak website, and comments in the form of contributions to a discussion appeared on the ultrasspartak website.

The second case was related to the protest against practice of the club, which has in cooperation with the police decided to close down the South curva (seat of the crowd) to provide for better safety in a stadium. The fans of Spartak Trnava have in response boycotted derby of Spartak Trnava - Slovan Bratislava (played on 23/09/2008). 2009/2010. 
Organization of boycott is neither easy in case that the match requires trip to another town. From the fans' point of view, boycott of the home match, particularly in case of derby with the greatest rival of Trnava, Slovan Bratislava, is almost unreal. The Ultras of Spartak have in response to closing down of the South curva, which has a rich history among the fans, called boycott of the derby. Situation in a stadium during the derby showed several interesting facts. First of all, a fact that the match was despite the boycott attended by about 7.000 people proves a strong football background in Trnava. The boycott was joined by all the fans from the ranks of the Ultras, and the derby was realized without the crowd, i.e. without cheering, proving on the other hand the group's strength and cohesiveness. At the same time, both of these situations prove that the Ultras groups exist independently of the other fans, and they are not responsible for behaviour of each other, even though they are trying to influence it. These events also show that there appears gradual limitation of competences and behavioural standards of the individual fan groups within the environment of the fans of Trnava. In spite of that, the general public still tends to judge all the fans equally on the basis of the predominating negative attitude created by media. In addition to the events which occurred on side of the home supporters - fans of Trnava, the guests - the fans of the Slovan Bratislava, have also caused some incidents. For example, they entered the closed South curva, they were throwing flares on the playing area, and eventually all of the Slovan fans left the stadium after 30 minutes of a game. The boycott called by the Ultras fans of Trnava can thus be considered to be successful.

Banners - use of the banners is the most frequently used form of a protest. They are efficient, accessible and so far have not been subject to restrictions by organizers or law. The banners are seen by large groups of people, since pictures of them bring them to the public notice, and thus they are visible also for the people not attending the match. The most often used themes of the banners are responses to the current affairs in the club, criticism of the Slovak Football Association, etc. The banners are not a new phenomenon; they were used already before formation of the Ultras, bearing similar purpose.

Chants, outcries and gestures - usually serve as an equally efficient expression of the fans' opinions as the above mentioned. Some chants, outcries or gestures are formed directly with the intention to criticize or protest, e.g. the chant "Trnava is our town" ("Trnava mesto naše je") was created in response to the criticism of the vulgar language used by the fans.

Stickers - are small visual manifestations of opinion or protest, often of a humorous nature. 
Contributions to the internet discussion - are efficient similarly to the banners or boycott and, considering the public access to the discussion, are also easily accessible. Wrong interpretation of the subject of contributions by insufficiently informed individuals, resulting in subsequent conflicts, poses a frequent problem. However, it is the best way to express one's attitude to the given situation. Discussion serves to express opinions and is available on several websites of the Trnava fans. It is a public matter, causing frequent conflicts in connection with the discussed topics or statements of some contributors. Period of disagreements in connection with the discussion contributions has resulted in password protection of the discussion website and in the intentional deleting of inappropriate contributions.

Clothes - represent certain form of a protest, too. E.g. T-shirts and hoodies with appliqués such as "antislovan", "antiantifa", "ACAB".

Fight against the modern football which from the fans' point of view endangers all contemporary activities of the Ultras groups, is another important form of the protest. The term "modern football" means series of measures aiming to increase safety in the stadiums. It concerns measures such as issue of tickets on names, seats in the stadium designed solely for sitting, sitting fans during the entire match, adapting the playing time to media in order to increase the viewer rating, significant increase of the ticket prices or ban on emotive after-goal celebrations.

According to the fans, it is intrusion of the personal freedom and possibilities of personal entertainment and self-realization during the football match. All the Ultras groups in Slovakia have adopted a disapproving stance on such efforts to push similar measures through. The following contribution gives a specific opinion of a Trnava fan to efforts to push through the modern football in Slovakia:

"Every fan likes to listen to his favourite chant in a stadium. Those who take it as a matter of fact should go and see a football match in the English Premier League. According to the football fans, an English fan is a bearer of everything of the best the Ultras fan should have. That's how it is, or rather how it used to be. Currently, if a football fan wants to see his club playing, he has to get a ticket issued to his own name, sit down, in case of a goal he is allowed to stand up for a while and clap his hands, or he will be warned by a steward that he would be forced to guide him out of the stadium if he doesn't sit down, in which case he would be naturally obliged to surrender his season ticket. No, thanks!" (R4, W.A. c.a., 23 years old). 
Similar measures are very difficult to be pushed through in our conditions, considering the financial situation of some clubs and stadiums, which are not in accordance with the standards, and therefore it is impossible to implement measures to the same extent as in England, for example. There was a change in connection with purchase of tickets for the football matches out of Trnava. In the past, fans were able to buy tickets before the match directly on the place of the match. Currently, the tickets are requested for in advance through an official representative of the fans, who is in charge of the sale. In case that the tickets are not requested for in advance, the fans are not let in the match, regardless of the distance they had to travel to see the match. An example is a situation of the fans of Košice, who travelled to Trnava for a match which took place on November 23rd, 2014. As they had not requested for the tickets in an official way, after reaching the stadium they were stopped by the police forces members, who escorted them back to the train station, where they had to get on a train back to Košice immediately.

The issue of introduction of similar measures to our environment is still relevant and unsolved, and is subject to an ongoing research.

\section{e) The Ultras and Violence}

The Ultras groups are formed on the basis of a need to organize a consistent presentation of a club, town and themselves by means of various activities during the football matches. Violence is not part of the Ultras ideology, as it does not correspond to the basic principles and values of the Ultras movement. ${ }^{31}$ However, in case of critical situations when for example a member or the entire group is in danger and need of protection, some forms of the violent behaviour are used. Most often, various moderate forms of manifestation of violence are used for protection, such as protests, outcries, vulgar gestures, pyrotechnics, etc. Physical violence and direct provocation of violent conflict are used by the Ultras members only as a last resort.

Phenomenon of the football supporting is still developing in our country and it is going through various changes. At the same time, it has to keep on adapting itself to more and more new and permanently changing conditions and the environment it lives in. Considering the unstable situation, definition of categories of the individual fans or fan

$31 \quad$ Main principles of Ultras in the part History and ideology of ultras movement, these principles were written by Italian fans and meet the rules of almost all of the European ultras groups. 
groups with respect to moderate and extreme manifestations of violence is relatively difficult.

Created typology of the football fans, described in the Masters Dissertation, suggests that fans always have to be assessed according to several above mentioned criteria. The given criteria are decisive also in case of the fans assessment with respect to use of individual forms of violence. The research carried out to this day has shown that the extreme manifestation of violence, such as extreme political views and direct physical violence, is not a group phenomenon, but is related solely to individuals. Moreover, the research has shown that the individuals pass such manifestation of violence on a group or a unit only in times of imminent danger (e.g. in case of conflicts during high-risk matches e.g. conflicts with the police, security service members, opponents' fans, etc.), when the entire group or a unit is adapted to such behaviour. Once the danger is averted, all forms of the radicalism become a matter of individuals with extreme form of the violent behaviour or extreme ideologies.

In the peace period, i.e. in time when the group is not in imminent danger, the strong opinion cohesiveness is partially deadened, and the individual way of thinking and behaviour takes over. Group of hooligans is rather an exception, as in this case the group cohesiveness in the way of thinking and behaviour remains unchanged also in the peace period. Thus, regarding the defined typology, the division assessing the football fans according to the individual and group behaviour is applicable.

As a general rule, people draw their ideas, rules, beliefs, goals and values from the environment they live in. Since this environment is influenced by the current political, economic and social situation, which is usually different for every person, response to this development also varies with the individuals (TILLY 2006:14).

In addition to the above mentioned aspects, the conflicts arising among the fans are influenced by the following factors ${ }^{32}$ :

The nation's nature - the nation's nature is influencing formation of groups and the conflicts they cause. In case of such influence, several aspects need to be considered:

Ethnic aspect - each ethnic group has its specifics, which are usually influenced by the living conditions in which the concerned ethnic group has developed, as well as by the 
elements absorbed by the ethnic group in the course of its development. On the ground of these facts, assessment of behaviour of for example English fans, that have created the hooligans groups and related manifestations, must be seen differently than the Italian supporters as creators of another specific group of the Ultras fans. The behavioural examples are spread among the Slavic countries differently, too. For example the Slovak fans who have been similarly to the others taking over the behavioural standards from more developed fan groups, are adapting these examples to their own needs and possibilities in our environment.

Historical aspect - as seen in the above, history takes significant part in formation and nature of the groups. Historical events accompanying the country development are reflected in the entire society, and similar types of groups appear in it as a proof, used by the rest of the society to fasten itself increasingly to the need to preserve life without any manifestation of violence, or more precisely life in peace.

Political aspect - the society is as well as the fan groups influenced primarily by the existence and necessity to observe effective laws. More significant aggression in form of direct clashes with the police is in our country often prevented by the level of risk, influenced particularly by crime of the Attack on the Public Officials, and strict punishments of the offenders. In some countries, e.g. in Poland, there is lack of such law, and thus the lower level of risk provides the Polish fans with greater freedom, and there are more frequent clashes with the police. This is one of the reasons why the Polish fans are in the absolute hooligans' top.

The group's nature - groups are formed on several levels:

State level - fan groups taking temporary form, solely for the purpose of support of their country, particularly during the representation football matches.

Regional level - fan groups created on the basis of favour towards the larger city clubs. Supporters take form in the entire region the concerned town belongs to, or even in some other Slovak regions. Similar groups were in the past only temporary, and supporters used to take form on the regional level only during attendance of the football matches. Currently, there are permanently active regional groups (e.g. North-east division associating fans of Spartak from the North-East part of Slovakia) created among the fans of Trnava.

Town level - despite the fact that they all support the same club and town, there are separate groups formed within a town (groups created according to a place of living in a specific quarter), and particularly in villages. This kind of group is characterized by strong 
cohesiveness and stability, and it usually survives also the peace period (i.e. times when there are no football matches).

Local level - groups created according to a permanent place in a stadium, representing the most frequent form of a group. More groups can be formed on one place or on the specific terraces in a stadium, but in our conditions, rivalry and subsequent clashes among such groups do not occur.

The individual's nature - behaviour of an individual usually depends on the personality precondition to the specific way of behaviour, as well as on the affiliation with a specific group. Unorganized and unapproved individual actions occur often at the football matches, resulting into violent clashes with the security forces members or the opponent's fans $^{33}$.

The above mentioned factors influencing origins of the conflicts among the football fans as a unit enable definition of specific types of the violent behaviour:

Violence among individuals of the same club - is rare; similar situation usually results from misunderstanding in case that the group members do not know one another, or it concerns confirmation of the leader's position or regaining of respect, or alternatively it can be a certain form of punishment for breach of rules.

Violence among different groups of the same club - even though there is larger number of groups and divisions with the Trnava fans, no greater conflicts or direct violent clashes were recorded among the groups.

Violence among groups of supporters of different clubs - this is the most frequent form of manifestations of violence among the fans. This sort of violence is rather frequent Dubnica and Trnava of 18/10/2008. "The match took place shortly after a qualification match with Poland for the 2010 World Cup. Mostly the younger supporters of the Spartak Trnava, inspired by the heroic fight of the Polish supporters with the security forces members, were during the match repeatedly attacking the organizers both verbally and using the pyrotechnics, chanting "Long live the kibbitzers!" The situation escalated after the fan of Trnava ran into the playing area, provoking a mass attack of the Trnava supporters on the organizers. The conflict caused the police intervention, attackers running away and hiding in the crowd. Some fans suffered light injuries even though they did not participate in the incident, but they did not manage to response adequately and avoid clash with the police." III-conceived behaviour of some individuals and consequent punishment of the mistaken persons is a rather frequent phenomenon of the football matches. 
particularly among the hooligans, which look for similar clashes intentionally. Other types of fans usually use verbal attacks, and the violent clashes are rare.

Violence against persons not belonging to the groups of the football supporters - it often concerns violence on the persons of a different race, nationality or religion. Even though there are individuals with various political attitudes and prejudices among the Trnava football supporters, race attacks are rather rare.

Violent clashes with the security forces members - violent clashes between the fans and the police represent a relatively complicated situation. Even though the police members are perceived as the biggest enemies of every fan, most individuals and groups are trying to avoid direct clash with the police. Direct clash with the police force members poses risks mainly due to the effective laws of the Slovak Republic (crime of the Attack on the Public Officials). Clashes with the police therefore occur only as a last resort in case of imminent danger, and the violence is limited to the verbal attacks or use of pyrotechnics. Different situation occurs in case of a conflict with an organizer or security service members provided for by the match organizer. Since they are not civil servants protected by the above mentioned act, the risk is lower and the clashes with the organizer's security service members are more frequent.

Definition of the fans' motivation to use various forms of violence is still questionable. The motivation for use of violence in case of the first two above mentioned forms, i.e. violence among the groups and individuals of the same club, can be illustrated by a specific incident, which occurred at the football match between Senec and Trnava on April 25th, 2008. Before the end of the match, an incident has occurred among the Trnava supporters, which is difficult to describe due to several available versions of the event: The events which are the same in all the stories are substantial. The story told by one of the fans: "First I've heard the version of one of the boys standing nearby the place of the fight, and he said that there was one of the ours (the Ultras) pissing among people, when one man asked him nicely not to do so, and so the fight began (maybe because they had already drunk something). The man who warned him not to piss there told him to better piss on our flags (for the performance of our players). If he told me so, I would beat him up, too" (R6, SST, 28 years old).

The incident has divided the Spartak Trnava fans in two groups (not counting the ones who have not given their statement or had not known of the event at all). On one hand there are supporters which agree with action of the intervening members of the group, which have instead of intervening against the inappropriately behaving member intervened against the man trying to provide for order, who should therefore be in the right. 
On the other hand there are the remaining supporters which do not agree with such action and believe that the members should have intervened against the inappropriately behaving member, without use of violence, and the fan should have only been warned regarding offence of the flags.

What does it imply? First of all it should be noted that acting of all participants was to a large degree influenced by consumed alcohol, otherwise the entire incident would have probably happened without violence or would not have happened at all. The fact that the group stood up for one of its members despite his inappropriate behaviour proves strong cohesiveness and unity of the group. Awareness of mutual protection and support under any circumstances provides the individuals of the group with sense of security. It dispels doubts about inclusion in the concerned group and attracts new members who feel the need to integrate and be protected. Demonstration of the group's strength and infallibility of the group's acting make the group untouchable. The fact that symbols are sacred objects for the group members and defamation of any symbol, in this case a flag, must be properly punished, is also important. As far as protection of the club symbols is concerned, both divided fan camps agree, the difference arises regarding solution of the problem.

The second camp is of the opinion that any violence done on own members is unacceptable. Defamation of a flag should be punished, but an appropriate form and environment should be chosen. The punishment should first of all concern the inappropriately acting member. There are contradictory views on the unit, the "big family", which is owing to these events overshadowed by an individual and a group he belongs to. It casts doubt upon actions of the concerned group and its leader. Considering the generally held view that actions of an individual or a group are reflecting actions of the unit, thus all the people which rank among the Trnava club supporters, such action is causing harm to an image of all the Spartak Trnava supporters, without exception. An individual becomes a unit and the unit becomes and individual. Similar events are therefore giving the impression that all participants of the event are acting in the same way, and this is how they are perceived by the outside world, which treats them that way. In this case an opposite situation develops compared to the previous case, when the individuals are discouraged from inclusion. However, the inclusion in this case concerns directly the unit, so-called "big family". It results in weakening of the group and threat of the group's break-up.

Violence against supporters of other football clubs is of completely different significance. This form of violence is not a new phenomenon, and it began to appear in our conditions as early as in the mid-sixties. Violent clashes have become organized since spread of the hooligans, and they are detached from activities of the unit. Clashes with the 


\section{DANIELA KUŠNIEROVÁ}

other fan groups do not have just a violent form, but verbal battles or competitions in cheering or performed choreo are sort of a fight too. Great importance is also attached to seizure of an opponent's symbol, such as flag or scarf, which is usually destroyed directly at the football match. The opponent's symbol is most frequently destroyed by burning it down.

There are several fundamental differences in understanding of the violence performed on members of one's own group and members of another fan group of another football club. While beating up a member of one's own group is perceived rather negatively (not excluding occurrence of such act), beating up a member of another fan group of another football club is considered as a heroic act. The same rule applies also in case of competition on the terraces or seizure of the opponent's symbol. The above mentioned example of use of violence on own member suggests, among other things, that while similar type of violence is in connection with one's own group of rather demotivating nature, it becomes motivating in case that violence is aimed at the opponent's fans. As a result, violence used among one's own ranks is weakening the group, while violence against the persons who are considered to be rivals is strengthening the group (TESA ̌ 2007:191).

In other cases, i.e. in case of violence used against the persons of a different race, nationality or religion, and also in case of conflicts with the police force members, it concerns relatively rare situations complicated mainly by the raised level of risk.

Level of risk is a decisive factor for use or non-use of violence and at the same time for selection of form of violence in case of the fan groups. Verbal attacks on the opponent's fans, players or the police members, as well as seizure of the opponent's symbols represent low risk, and are therefore the most frequent moderate forms of the violence manifestation. Violence to property, in this case damage to equipment of a stadium, breaking a police car or organized meeting of fans out of town represent medium level of risk and are the second most frequently used forms of manifestation of violence. The least frequently used form of violence is a direct violent attack on the police force members or the security force members. Such clash represents high level of risk. The risk is presented by crime of the Attack on the Public Officials, strongly affecting the person committing such offence.

Number of participants taking part in the committed violence is reflected by the level of risk. While the verbal attacks on the police members, opponent's fans or other persons or organizations are joined by almost all or majority of the match attendants, any direct confrontation with the police is joined by a minimum amount or smaller part of the football match attendants. 
Another important criterion provoking possible manifestation of violence by an individual or a group is motivation to use the violence. Motivation to use the violence can be various and it most often depends on type of the individual or the fan group.

In case of hooligans, the most often motive to use violence is an obligation to protect interests of one's own group and unit.

In case of the remaining part of the fans, use of violence has several reasons:

- anger as a response to grievance (it concerns all types of fans)

- protection from imminent danger (it most often concerns the Ultras and hooligans groups)

- frustration, effort to wreak one's anger (it concerns mostly individuals)

\section{Particular Examples of Violence Among Football Fans}

Based on the aforementioned factors that affect motivation and choice of used form of violence among the football fans, we can define particular examples of violence used among the fans. The violence can be categorised on two basic groups:

1. Moderate form of manifestation of violence

2. Extreme form of manifestation of violence

\section{Moderate form of manifestation of violence}

A moderate form of violence is present among the fans individually as well as collectively.

Individual violence manifestations can have various forms. Most of all they often result from a thoughtless actions of an individual, usually a youngster, which is not familiar with examples and behavioural standards of the group members. The individual is often anonymous for the group and it is usually an occasional visitor that only goes to important football matches with a large number of participants, and the anonymity of the crowd offers him the opportunity to use a form of moderate violence. In this case, it is usually damage to property, e.g. pulling out seats of the stadium, breaking a window on a police car etc. Another example is an individual as a part of a group, that uses this kind of behaviour as a way of gaining respect of the older members of his group and of becoming a fully-fledged member of his group. The best way to achieve this is the use of pyrotechnics or 


\section{DANIELA KUŠNIEROVÁ}

alternatively protecting the members in case of real threat of physical attack. The last option is usually the action of an older member of the group that uses moderate violence for various reasons (to determine the exact motives of older members is relatively complicated, because the reasons behind their actions are usually personal and it is relatively difficult to gain this kind of information). The reaction to the action of the older member is usually the involvement of the entire group, which will develop into a collective form of violence.

Collective violence means the participation of the majority of the persons present at a football match and similarly to individual violence it varies in intensity. The least serious form of moderate violence is the use of vulgar language, gestures, chants or throwing various objects on to the football pitch (plastic beer cups, lighters, papers, pyrotechnics etc.).

Although no law forbids the use of vulgar language and gestures in public, it is these manifestations of violence that become the focus of the attention and criticism of the general public. The use of vulgar language by the fans can have multiple reasons:

Insult and disgrace of the opponent - for example the fans of the rival football team, the representatives of the Slovak Football Association, members of a different club, the players from the rival team etc. In this case, the vulgarisms represent a "demonstration of power" ${ }^{34}$ of the group. Vulgar language, gestures, shouts and chants are in this case always used by all the members of a group or a unit present at the match.

Form of entertainment - concerns the same opponents as in the previous example, but in this case we are talking about individual manifestations of the members of a group, that use words and gestures to mock a particular rival.

Manner of defence and release of anger - usually aimed at the police or the organisers, this is the most usual reaction of the football fans to inadequate interventions of the police or provocations on the part of the organiser. Depending on the situation this form of moderate violence can be individual or collective.

When it comes to throwing objects on the football pitch, it is more an action of an individual rather than a group. The reason behind this behaviour is usually disagreement with what's happening on the football pitch. Throwing objects onto the football pitch includes two alternatives: 
The first alternative is a part of choreography that uses quiet pyrotechnics thrown into the parts of the football pitch outside of the playing area itself, and does not present a threat to the players or the game. This type of violence is tolerated and supported by the other fans.

The second alternative is uncontrolled behaviour of individuals who use various objects (lighters, cups, and loud pyrotechnics), throwing them onto the playing area of the football pitch, thus threatening the safety of the players and the game. This type of violence is usually not tolerated neither supported by the rest of the fans.

Another, more serious form of moderate violence is damage to property. Most usually we speak about pulling out the seats of the stadium, starting fire directly on the terraces (ritual burning of the seized scarf or different symbol of the opponent's club, therefore the primary goal is not to damage property) damage to the equipment etc. The reason of classifying the damage to property among various kinds of moderate violence is the fact, that in this case, it very seldom leads to bodily injuries of the participants and the damage is usually covered by the football club. This form of violence usually comes hand in hand with the initial outburst of anger as a reaction to the feeling of injustice (inadequate intervention of the police, provocations and interventions of the organisers, etc.).

The most serious form of moderate violence is a direct physical contact (including shoving or fist fights that do not lead to injuries requiring medical attendance), which is caused by a total outburst of emotions accumulated during the football match and it usually only occurs after the first two stages.

\section{Extreme form of manifestation of violence}

Similarly to other countries, in Slovakia we too encounter groups of football fans with extreme political opinions and prejudices. We mainly talk about extreme forms of violence manifestations such as racism, xenophobia, anti-Semitism etc. In addition to the aforementioned, there is a developing occurrence of extreme nationalism and local patriotism rising among the football fans. Extreme forms of violence also include direct physical contact resulting in bodily injuries or death that is usually connected with the stated political views and prejudices of the fans.

Most often, the football fans are connected with the manifestations of racism. According to the testimony of several respondents, this kind of discrimination is spread by the skinhead movement, which started to join the fans. They have gradually assimilated and spread their ideology to the rest of the fans. It became, to a various extent, a part of the 


\section{DANIELA KUŠNIEROVÁ}

ideology of the fans and their consequent behaviour. Among this affected group of fans the ideology has changed its original form and softened the extreme aggressive manifestations (concerning groups of fans as wholes, not behaviour of individuals). This means that the fan groups are secondary propagator of the ideology, not its primary creator.

Beginning with the spread of the Ultras in Trnava, this type of violence manifestation gradually disappeared and ceased to exist, and any manifestations of racism during a match or else are currently not tolerated by the fans.

Anti-Semitism acquires more of a passive form among the fans; and the purpose is not to discriminate, physically attack the rival group for their race, religion or nationality, but simply to insult them. The group that this abusive language is used against does not have to be (and usually isn't) Jewish, the language is used with the objective to humiliate and insult the group. Similar language is most often used against the fans of Trnava's biggest rival - Slovan Bratislava. The manifestations are typically:

- Verbal - pejoratives - schmoes ("obrezanci"), Jews ("judáci, židi") (and various alternatives of these)

- outcries - whole Bratislava jude, jude, jude ("celá Blava jude, jude, jude")

- chants - "Slovanista"

- Visual - posters or banners as a part of choreo, symbols, stickers, etc.

Xenophobia has a relatively peculiar form among the fans. It represents the fear of any individual, that is not a member of their club, therefore not a member of "the big family". In this case, the fear results from a strong belief, that all those, who are not members of the group, have for their objective to find out internal information about the group and use them against the group. This type of phobia is more common with individuals than groups or units. It mostly occurs in groups with older members who strictly follow the rules and ideas of their group and promote them.

Despite the fact that manifestations of nationalism are present among Trnava fans, local patriotism is more deeply rooted in this community. On the scale of values of Trnava fans, the town is the most important and the state comes second. Nationalism is manifested more evidently in matches against, say, Dunajská Streda, whose fans are of the Hungarian minority and present themselves as such during the football matches. This kind of encounters tends to be very emotional and include the use of club symbols as well as national ones. 


\section{Conclusion}

Considering the uniqueness of the environment of football fans and the specific way of their actions and thinking, the accumulation of information is a long term issue. The information recorded so far give us a basic view of formation and functioning of the Ultras of Trnava. The above text suggests that the football fans created not only a specific kind of a group but also a special way of life. Their allegiance to the club is manifested not only at a football match, but also outside of it, in everyday life, which is not fully understood by the rest of the society.

During the development of the football fan base in Trnava, cheering itself underwent significant transformations and now includes more sophisticated visual and verbal creations. The transformation of the way of thinking and behaviour of the Trnava fans is equally important. The most significant shift was monitored in one of the most extreme forms of manifestation of violence - racism, its manifestations were completely set aside from the lines of the fans after the spread of ultras groups in Trnava.

The ongoing changes in the environment of the football fans, as well as the lack of accessible information from the football fans environment in Slovakia mean that further research is needed.

\section{Bibliography}

ARENDTOVÁ, H. (2004): O násilí. Praha: Alfaprint.

MAREŠ, M. - SMOLÍK, J. - SUCHÁNEK, J. (2004): Fotbaloví chuligáni. Brno: Barrister \& Principles.

SMOLíK, J. (2008): Fotbalové chuligánství. Historie, teorie a politizace fenoménu. Karlovy Vary: Zdeněk Plachý.

TESAŘ, F. (2007): Etnické konflikty. Praha: Portál.

TILLY, Ch. (2006): Politika kolektivního násilí. Praha: Sociologické nakladatelství.

\section{Web Sources}

www.ultrasspartak.sk

www.spartak.sk 
DANIELA KUŠNIEROVÁ

\section{Ultras in Trnava: History, Activities and Ideology}

www.biliandeli.sk

www.ultras.sk

www.ultrasgang.sk

www.hooligans.cz

http://www.humanisti.sk/view.php?cisloclanku=2008110003- Jusko, Peter

http://www.humanisti.sk/view.php?cisloclanku=2008110006- Ondrejkovič, P.

http://www.humanisti.sk/view.php?nazevclanku=nasilie---spolocensky-neziaduci-jav-1cast\&cisloclanku=2008110006

http://www.humanisti.sk/view.php?nazevclanku=nasilie---spolocensky-neziaduci-jav-2cast\&cisloclanku=2008110008

http://www.humanisti.sk/view.php?nazevclanku=nasilie---spolocensky-neziaduci-jav-3cast\&cisloclanku=2008110009

http://www.humanisti.sk/view.php?nazevclanku=nasilie---spolocensky-neziaduci-jav-4cast\&cisloclanku=2008110010

http://www.humanisti.sk/view.php?nazevclanku=nasilie---spolocensky-neziaduci-jav-5cast\&cisloclanku=2008110011

Výskum mládeže:

http://www.vyskummladeze.sk/images/stories/iuventa/PRIESKUMY/PKD005/Autorefer at_a_dotaznik.pdf- 8.4.2009

Návrh zákona SR:

http://www.rokovania.sk/appl/material.nst/0/10E2A538F72D4B3EC12570EA004C0609 /\$FILE/Zdroj.html

Štúdia SIRC: http://www.sirc.org/football/football_passions.pdf

Štúdia organizácie L'udia proti rasizmu:

http://futbal.rasizmus.sk/wp-content/uploads/hooligans-sk_web.pdf

\section{List of Respondents}

R1- member of group Suthsidetrnava (SST), Age: 36 years, Town: Trnava

R2- member of group Northsidepatriots (NSP), Age: 30 years, Town: Trnava

R3- member of group Northsidepatriots (NSP), Age: 24 years, Town: Dechtice 
R4- member of group White Angels, c.a., (W.A., c.a.), Age: 23 years, Town: Chtelnica R5- member of group White Angels, c.a. , (W.A., c.a.), Age: 58 years, Town: Trnava R6- member of group Southsidetrnava (SST), Age: 28 years, Town: Špačince R7- member of group Gang of Piešt'any (GP), Age: 20 yeras, Town: Piešt'any R8- member of group Gang of Piešt'any (GP), Age: 26 years, Town: Piešt'any 